\title{
Dealing with mine closure planning liabilities, opportunities and lessons learned
}

\author{
MB Dagva QMC LLC, Mongolia \\ Ts Davaatseren Erdenet Mining Corporation, Mongolia \\ Kh Vladimir Erdenet Mining Corporation, Mongolia
}

\begin{abstract}
In 1978, Erdenet Mining Corporation (EMC or Erdenet) was established in accordance with a joint venture agreement between the governments of Mongolia and the former Soviet Union $151 \%$ and $49 \%$, respectively). As one of the largest ore mining and processing operations in the world, the company produces approximately 530,000 tonnes of copper concentrate and 4,500 tonnes of molybdenum concentrates annually.
\end{abstract}

The company plans to expand its productivity from 26 mtpa to $32 \mathrm{mtpa}$ due to declining ore grade, to retain competiveness and also to hold revenue at a consistent level. Consequently, a number of issues became apparent that were not identified in the decision-making process for the expansion approval. What was initially thought to be a gradual process of developing and integrating mine closure plans (MCP) for the mine operations over the life-of-mine, this expansion now requires a MCP for the decommissioning of the old tailings storage facility (TSF) and a MCP incorporated into the design of the new TSF.

This paper examines a number of issues and opportunities that accompany expansion changes to a 37-year-old mine. Firstly, the MCP needs to be integrated into the company's business plan. A mid-term business plan update (2016 to 2025) is in progress. The number of items were determined which were relevant to mine closure within this timespan. For example, the existing TSF is at approximately $60 \%$ of its initial design capacity; a new TSF will need to be constructed during the next 10-14 years. The old TSF will require a MCP to deal with drainage and groundwater contamination, existing dust issues, rehabilitation and ongoing monitoring and remediation. By contrast, the new TSF will include mine closure considerations during the design, construction and operation; an ideal opportunity to reduce post-closure monitoring, costs and ongoing liabilities.

Erdenet town was established in 1974 specifically for the mine and now has a population of around 110,000. Public participation will be adopted for the first time during the new TSF/MCP development process and for the old TSF closure. This paper will also touch on the changes in town dynamics since the mine's conception and what this may mean to the mine closure process.

\section{Introduction}

Since its first commercial production in 1976, Erdenet Mining Corporation's (EMC or Erdenet) role has been vital to the Mongolian economy. Over the past 10 years, its peak contribution to the Mongolian state budget was 31.7 per cent in 2006, declining significantly to around six per cent in 2014. This is predominantly a consequence of newly commissioned mining projects over this period.

Erdenet City (Figure 1) is one of the youngest settlements in Mongolia. It was founded in 1974 in an area where large deposits of copper had been discovered in the 1950s. The initial plan was for 8,000 miners to live in a newly established town with their families. Assuming four to five members per family, the town was built to accommodate 40,000 to 50,000 people. Today it is the third largest city in Mongolia with more than 110,000 inhabitants. 


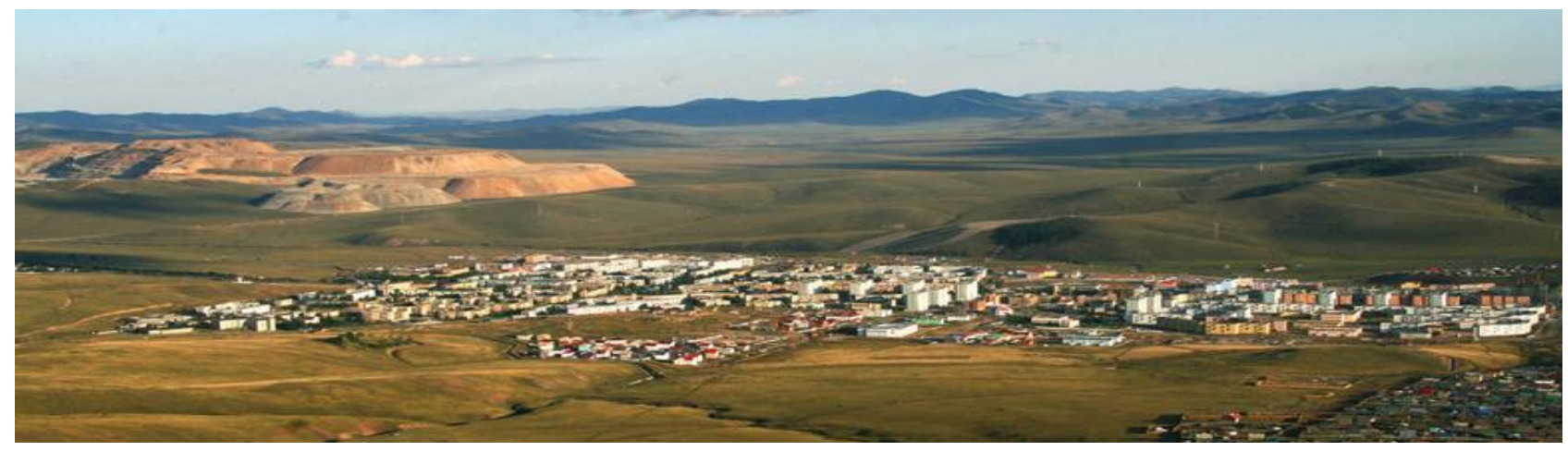

Figure 1 Erdenet city and waste rock dump (background)

Erdenet was the first copper mine in Mongolia and is a unique case when considering mine closure issues. There are no other large-scale hard rock mining operations nearing closure for tailings storage facilities (TSFs). There are, however, some small-scale placer gold, coal and fluorite mines nearing full mine closure. As a point of interest, according to data collected in 2014 by the Ministry of Environment and Green Development (MEGD 2015), a total of $13,371.43$ hectares has been disturbed and abandoned as a direct result of mining activities. Of which 2,141.5 hectares is classified as 'CLASS A - requiring urgent rehabilitation'. As a consequence, new regulations were developed for small-scale mining, including guidelines for mine rehabilitation.

Since 2013, EMC started addressing closure liabilities and integrating them into business and mine planning. In 2015 the company decided to update its regular 10 year conceptual level business plan in order to reflect current market conditions, declining ore grades, retain competiveness and to hold revenue at a consistent annual level of 120,000 tonnes of copper.

EMC held an expansion opening ceremony 20 May 2015, whereby many government officials from both Mongolia and Russia attended, including the President of Mongolia Mr Elbegdorj; Ambassador of the Russian Federation to Mongolia, Mr Azizov Iskandor Kubarovich; Ambassador to Belarus to Mongolia, Mr Stanislav Vladimorovich Chepurnoi and many other guests (Figure 2). The processing capacity will increase by six million metric tonnes to a total of 32 million metric tonnes annually.

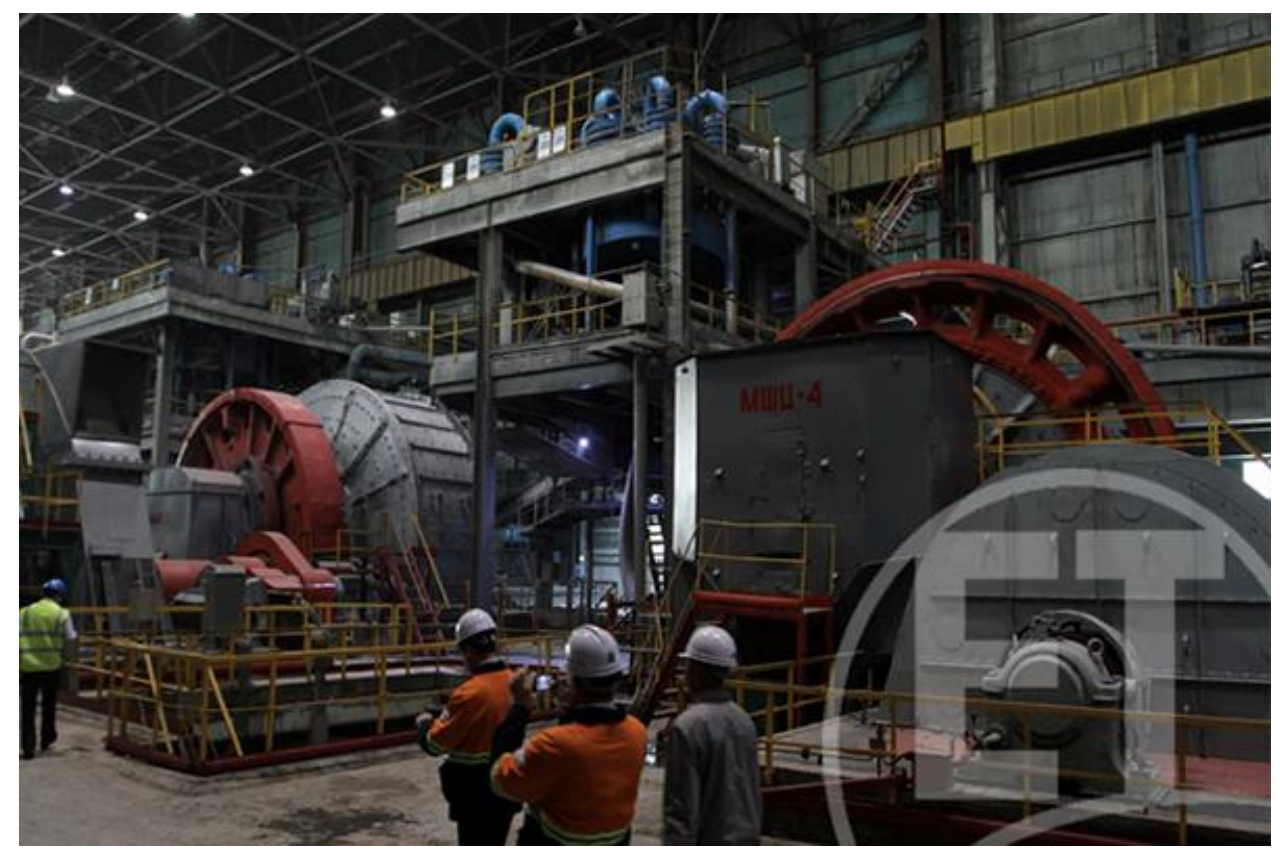

Figure 2 Erdenet Mine processing plant expansion 


\section{Key aspects of mine closure need to be integrated into the business plan}

A general mine closure plan with additional recommendations of best practices was produced as a work package to assist EMC's management decision-making process (Figure 3). As part of that work, it was identified that EMC needs to close its current TSF and build a new TSF in the coming 10 to 15 years depending on production rate variation. EMC's decision was to proceed with the development of the concept plans for mine closure and to integrate mid-term closing items into the company's ten-year business plan.

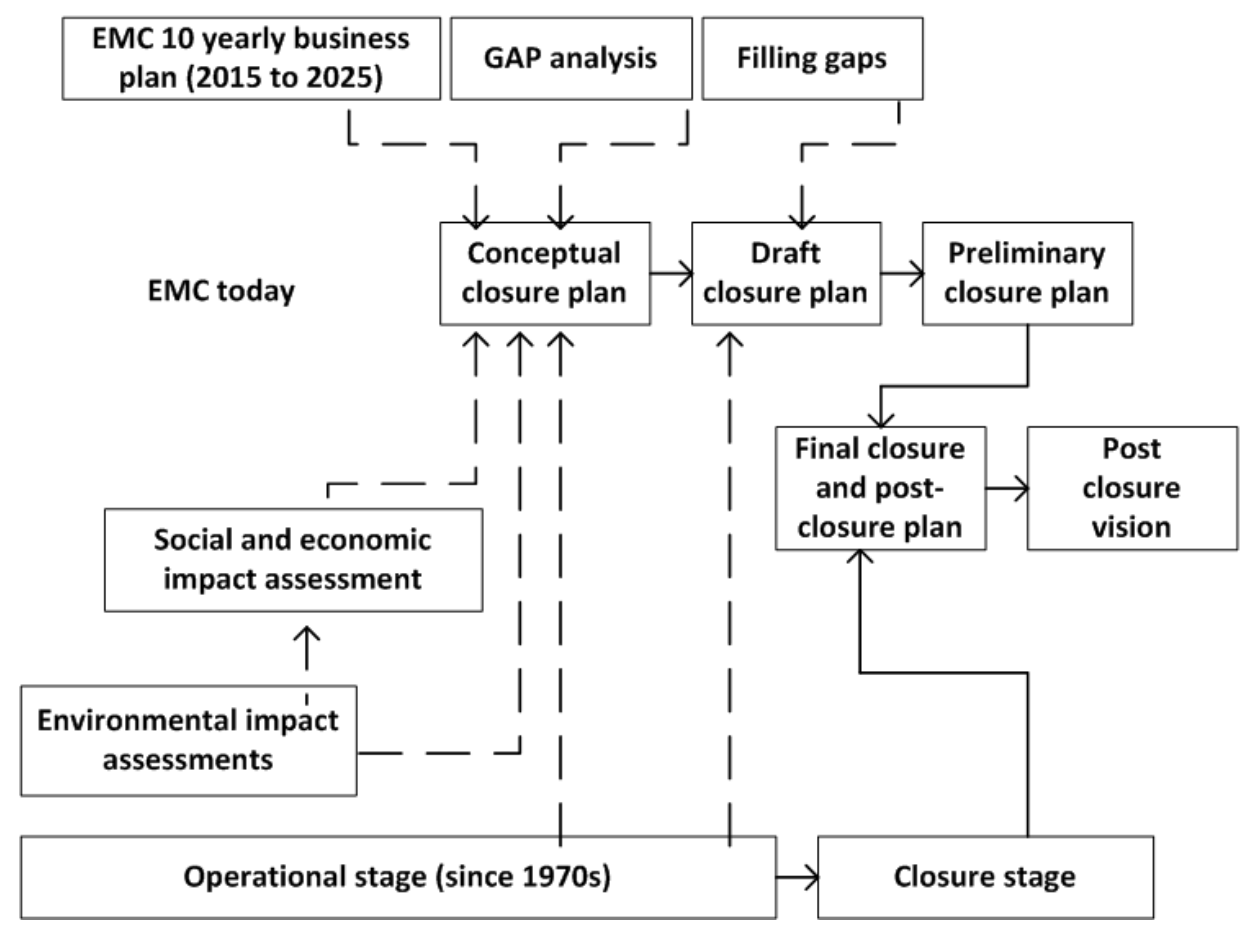

Figure 3 EMC Mine closure planning stages

EMC utilises a 10 yearly conceptual level business plan as a tool for mid-term visioning. Previous conceptual plans focussed mainly on technical aspects of the business. One key philosophy was to maintain the volume of saleable metal in the concentrate in order to maintain company competitiveness. Consequently, a continuous increase in milling capacity was required to offset the decreasing copper grades (Figure 4).

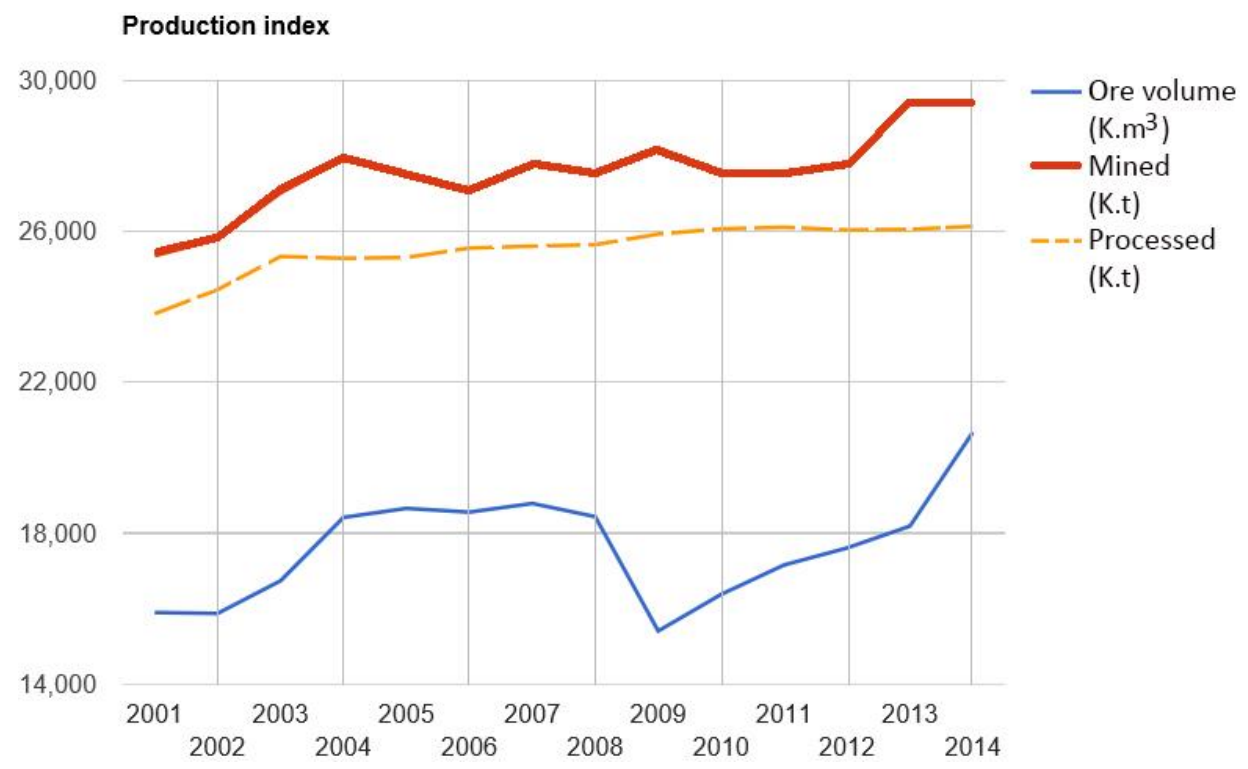

Figure 4 Erdenet Mine production (2001-2014) 
EMC is currently developing the $2016-2025$ conceptual plan, which is the first 10 year conceptual plan to include mine closure strategies and considerations.

To aid this process a working group consisting of some 40 participants has been established. The working has two sub-groups to cover the Technical aspects and Mine Closure aspects of the business plan.

The Technical team is covering the following:

Technical aspects: the copper market outlook and economics in the coming 10 years suggests that EMC should concentrate on efficiency rather than simply increasing its yearly production rate. For example, installing operational management systems, adapting the lean six-sigma approach, changing conventional truck haulage to in-pit conveyor crusher, and converting tailings disposal to paste or dry stacking are some key technical considerations. What dictates the type of transportation system best to manage the tailings cost efficiently, depends on the tailings properties, tonnage and site landscape. There are a number of tailings transportation choices, for pumped slurry pipeline systems, gravitational pressure pipeline systems and channel free gravitational flow can be used; for wet cake, conveyors or trucks are options.

The Mine Closure team is covering the following:

Mine closure aspects: introduce mine closure management systems, regional sustainable development, closure related economic and social aspects, public participation, closure costs, closure fund, water conservation, rehabilitation research, groundwater remediation and protection etc. are being included in the conceptual plan.

There are a number of issues and opportunities that accompany expansion changes to a 37-year-old mine, for example, increased infrastructure for water and power supplies, more area for WRD and TSF. What was initially thought to be a gradual process of developing and integrating mine closure plans (MCP) for current productivity rates, this expansion now requires a MCP for the decommissioning of the old TSF and a MCP incorporated into the design of the new TSF. The new TSF will include Mine Closure considerations during the design, construction and operation, an ideal opportunity to reduce post-closure monitoring, costs and ongoing liabilities.

\section{$2.1 \quad$ Tailings storage facility}

The existing TSF is approximately $60 \%$ of its initial design capacity; with the expansion, a new TSF will need to be constructed during the next 10-14 years. The old TSF (Figure 5) will require a MCP after the fact to deal with drainage and groundwater contamination, existing dust issues, rehabilitation and ongoing monitoring and remediation. By contrast, the new TSF will include Mine Closure considerations during the design, construction and operation, an ideal opportunity to reduce post-closure monitoring, costs and ongoing liabilities.

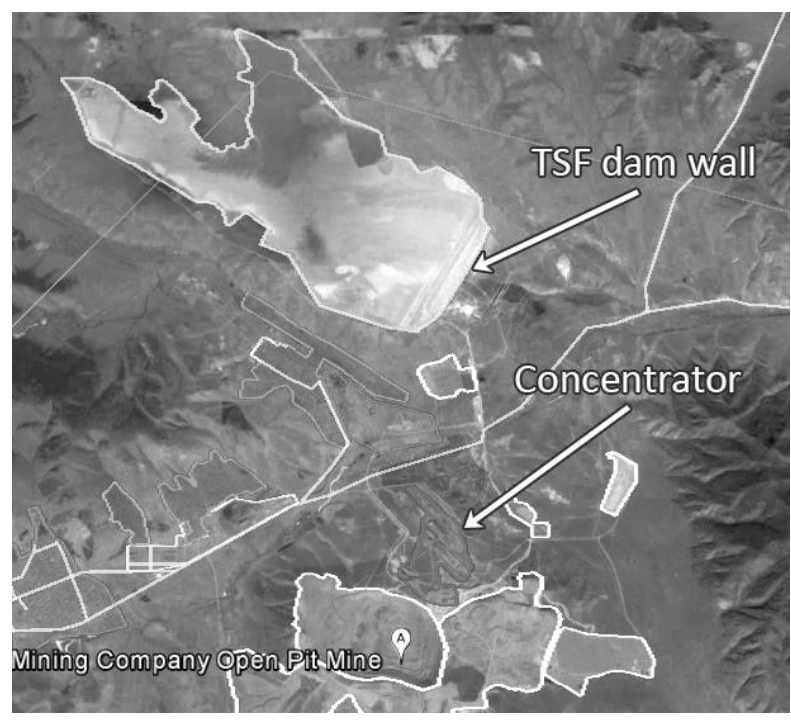

Figure 5 Erdenet Mine tailings storage facility overview 
The existing TSF design was developed back in mid-1970s as part of the mine development by a former soviet design institute. Cost saving was the key criteria for site selection. The TSF was selected by its geo-morphological advantage. Positioned in a nearby valley catchment, the upstream embankment (Figure 6) design method and a single cell discharge point were seen as the most advantageous and cheapest of the options. The concentrator location was higher than the proposed TSF, which meant pumps were not required, allowing a natural flow to feed the TSF with a 30-70\% ratio of solids to water slurry, respectively (Gravitational Pressure Pipeline System), (Engels 2006). A third party engineering company (MehnaBor Engineering) is responsible for the maintenance, auditing and yearly construction planning and upgrades. The key technical specifications (Table 1) of this TSF shows that this facility is now in the middle of an active depositional phase.

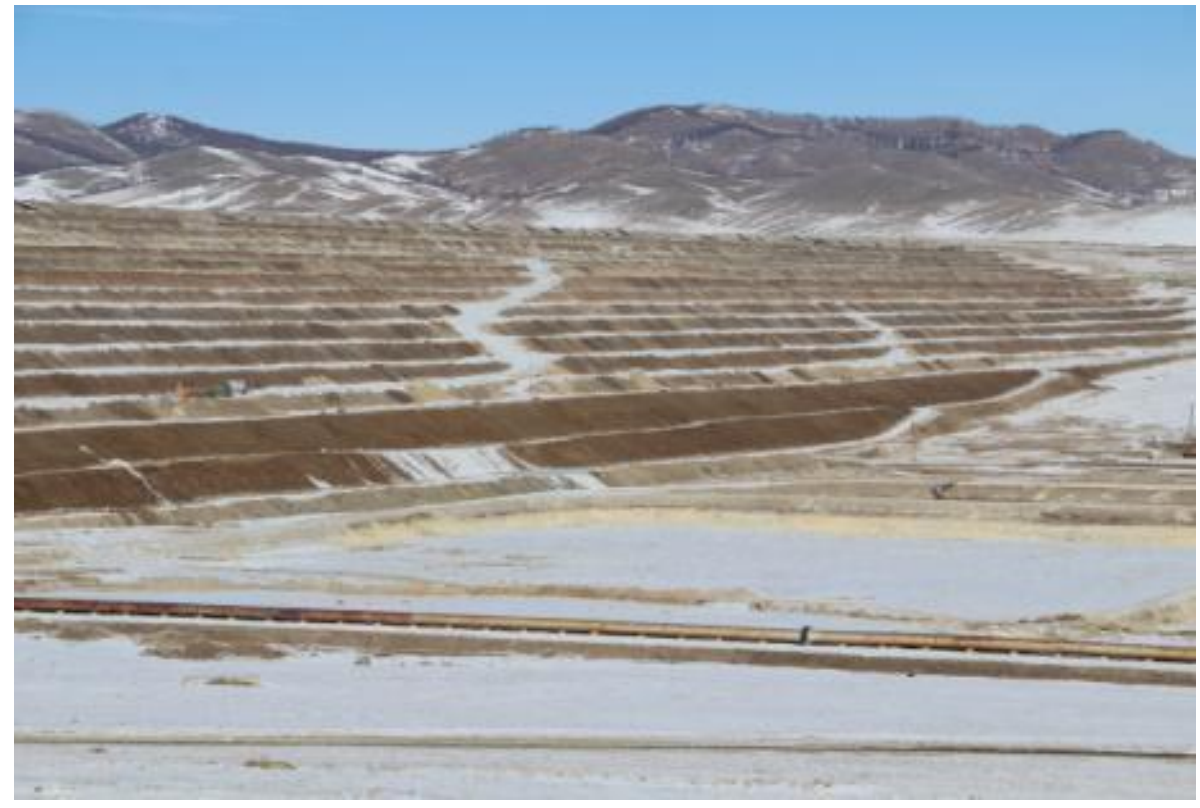

Figure 6 Upstream embankment design with valley and surrounding mountains at Erdenet Mine

Table 1 Key specifications of tailings storage facility at Erdenet Mine (as of January 2015)

\begin{tabular}{ll}
\hline TSF operational specifications & Current status \\
\hline Overall area & $\sim 1,860$ ha \\
\hline Embankment area & 140 ha \\
\hline Sand deposited area & 1,373 ha \\
\hline Lake area & 348 ha \\
\hline Contained water & 27 (MCM) million cubic meters \\
\hline Total sand volume & $718(\mathrm{MMT})$ million metric tonnes \\
\hline Design capacity & 1,700 (MCM) \\
\hline Current embankment level & $1,300 \mathrm{~m} \mathrm{RL}$ \\
\hline Design embankment level & $1,320 \mathrm{~m} \mathrm{RL} \mathrm{(1,340m} \mathrm{RL} \mathrm{under} \mathrm{consideration)}$ \\
\hline
\end{tabular}

Over time it became evident that the selected design and method was the cause of many operational, environmental challenges such as white dust, excessive water loss, ground and surface water contamination, excessive water usage and dam wall seepage. As part of conceptual plan, EMC included a full investigation programme to be launched for the existing TSF in order to determine full environmental and social impacts and potential risks. 
Currently the TSF contains approximately 60 per cent of its designed capacity indicating another 10 to 14 years of expected deposition.

Actions planned for the existing TSF are:

- Review of national and international documentations on tailings storage facility management including regulations, standards, manuals, technical papers and conference proceedings for design, construction, operation and closure stages in order to determine potential gaps in the current tailings management system. It is also believed that Mongolian national regulations need to be updated in the coming years in order to reflect international best practices, such as the "Guidelines on the safe design and operating standards for tailings storage" (DME 1999).

- The TSF has been developed progressively over a period of 35 years (with the embankment being raised on a year by year basis), and another 12 to 15 years of depositional life is left for this facility. Operational experience suggests that there might be loose or poorly consolidated material with some frozen layers of water deposited just behind the embankment. A full scale hazard rating study, in accordance with internationally accepted standard, is envisaged to determine the potential impacts in terms of the nearby Erdenet town and communities along the downstream valley in the event of the TSF failure.

- Preliminary and detailed closure plans for the TSF for safe, stable and aesthetically acceptable closure are to be undertaken. Side considerations are the potential application of deposited material and even copper recovery from the facility. Pre-feasibility level evaluation with interested parties is planned. Detailed full cost estimation of TSF closure will be commenced and integrated into the business plan.

\subsection{New tailings storage facility}

Poor construction of TSF can create lasting environmental impacts if the principles of best practice environmental management are not used during planning, design and the operational stages. Impacts are generally related to ground and surface water contamination, dust, embankment instability, erosion, aesthetics and poor rehabilitation practices. These potential impacts can be avoided or mitigated if given the appropriate consideration during the planning stage, which then enables proper assessment and choice of the most suitable operational technology available. Once designed and operational, effective environmental monitoring and auditing will also help reduce the risk of any environmental impacts (Davies et al. 2002).

EMC is now identifying a number of key factors for the new storage facility location and construction thereof, and are including the best available technology for site geotechnical and environmental characterisation; determining best appropriate design following location selection; method of transport and storage (dry stack etc.); use of cells or not; environmental risk management; and the life of TSF.

Following are some of the challenges and opportunities identified during the early evaluation stage:

- Cold and dry climate. It was evident from the current single cell TSF operation, it is hard to manage frozen layers during spring and the dust in summer.

- Elevation of potentially available locations for the new TSF were higher than the current location which requires pumping for discharge.

- Top soil from the new TSF area can be used for rehabilitation of the current TSF.

Actions planned for the new TSF are:

- A detailed site selection study for the preliminarily targetted area with consideration of the impact of the new facility on the surrounding environment, either during operation or after closure. The proximity of the densely populated Erdenet city. 


\section{Change in community dynamics since mine commencement}

Erdenet town was established in 1974 specifically for the mine with an estimated population of 8,000. The population currently stands around 110,000 , depending on the influx of people relocating from other cities for higher salaries and others leaving their traditional nomadic herder life for employment. The effects of relocation have progressively worsened as the unemployment figure (EMC 2015) is now more than double the national average. At the same time, Erdenet has become an important trading centre for cashmere, wool, meat, paper manufacturing and metal processing. There are also plans to establish a national medical research centre, engineering training facilities and machinery industry.

In the mid-1980s, more than 50\% of Erdenet consisted of Russians working as engineers or miners. After the fall of Soviet Communism (1990), most Russians left Erdenet. Today only about eight per cent of the population is Russian. Approximately half of the Erdenet population live in old Russian built apartments which are connected to water, power and sewage, while the other half of the population live in the Ger district (Mongolian traditional nomadic tent like structures) on the outskirts of the city with no access to utilities.

Erdenet City has developed from a small mining town to the third largest city in Mongolia, to what most Mongolians regard as the proven model for large mining companies to follow.

The local economy is overly reliant on EMC's mining operation. Over the last 10 years, $88.2 \%$ of the Orkhon province budget is comprised of EMC paid taxes (Figure 7).

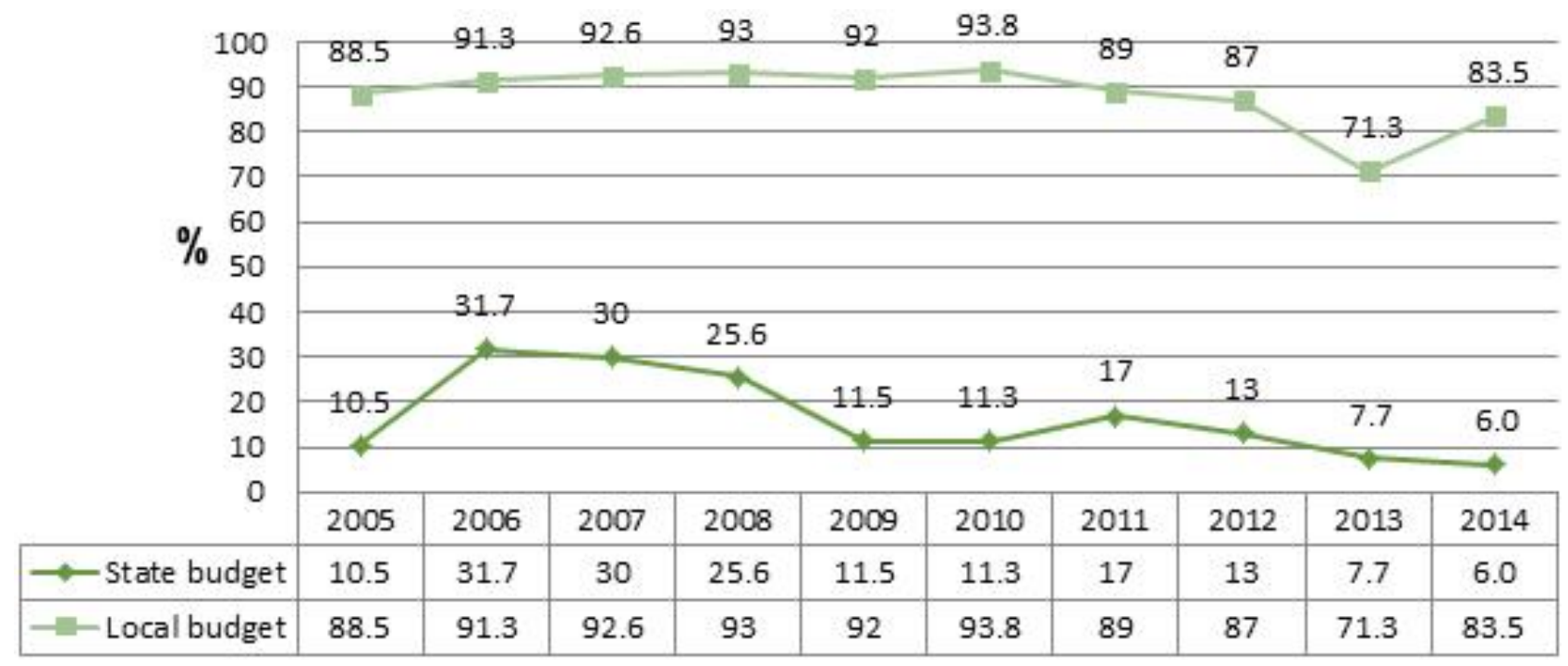

Figure 7 Erdenet Mining Corporation's taxes and duties in state and local budget (EMC 2015)

From the above table, EMC's contribution has declined since 2006 due to other mining ventures coming online. The concern is the Orkhon Province's budget is reliant on the mine. This may not be a true reflection of actual distribution. Provinces that have large mining companies in their jurisdiction do not receive support funds from the National Government.

Some of the environmental and social issues identified during one of the community consultation workshops are shown in Table 2. 
Table 2 Social and Environmental concerns: TSF

\begin{tabular}{llll}
\hline \multicolumn{1}{c}{$\begin{array}{c}\text { Concerns identified } \\
\text { by the company }\end{array}$} & \multicolumn{1}{c}{$\begin{array}{c}\text { Concerns identified } \\
\text { by local governors }\end{array}$} & \multicolumn{1}{c}{ Public concerns } \\
\hline - Sewage operation & - Traditional Ger districts and & - Unemployment $16 \%$ \\
- Leachates & accommodation & - Dust \\
- White dust & - Dust & - Sharing information about \\
- Groundwater & development after mine & - Air, water, soil pollution \\
contamination & closure & - River bank protection \\
- Water supply, water & - Garbage & - Lack of medical service \\
consumption & - Sewage water treatment & - Pollution of vegetables \\
- Bummunity involvement availability & Community involvement & - Timber supply \\
& - Lack of revenue source & - Poverty; elderly care \\
& & - Business \\
& & - Water and power supply \\
\hline
\end{tabular}

\section{Conclusion}

In 2015, Qualified Mining Consultants (QMC) LLC presented a paper (Dagva et al. 2015) at the 10th International Conference on Mine Closure in Vancouver on the "Challenges of integrating mine closure plans mid-way through the life of mine in Mongolia". The paper discussed the challenges of integrating best practice mine closure into an established mining operation and its subsequent liabilities, considering the advancements in technical knowledge and mining practices since the mine's inception, and the potential influences of changes in mine management, political parties and policies. This paper examines a number of issues and opportunities that accompany expansion changes to the 37-year-old mine.

As shown in our 2015 and 2016 Mine Closure conference papers, the complexity in developing a mine closure plan is no easy feat. Mine closure plans require continual review, must be flexible enough to accommodate change; must contain effective planning through research, testing, modelling, monitoring for continual improvement; must include regular auditing of management systems and, importantly, contingencies for the unexpected or unplanned. Policies and laws need to be developed to support the implementation of mine closure for responsible and sustainable mining. Unfortunately, government institutions are still developing in Mongolia and policies can change, resulting in inconsistencies with implementation and regulation.

EMC's objective is to remain operative and always competitive in the market place by holding revenue at a consistent level. Due to decreasing ore grades, EMC needs to increase productivity by $6 \mathrm{mtpa}$ to $32 \mathrm{mtpa}$ to maintain this revenue target. A 37-year-old mine can learn from time gone by and seek opportunities from new technology; this an exciting time for EMC and Mongolia.

\section{References}

Dagva, M, Glen, A, Davaatseren, Ts, Vladimir, Kh \& Erdenetuya, O 2015, 'Challenges of integrating mine closure plans mid-way through the life of mine in Mongolia', in AB Fourie, M Tibbett, L Sawatsky and D van Zyl (eds), Proceedings of the 10th International Conference on Mine Closure, pp. 805-816.

Davies, MP, Lighthall, PC, Rice, S, Martin, TE 2002, 'Design of Tailings Dams and Impoundments', Tailings and Mine Waste Practices, SME, AGM, Phoenix.

DME (Department of Minerals and Energy, Western Australia) 1999, Guidelines on the safe design and operating standards for tailings storage, The Government of Western Australia.

Engels, J 2006, Tailings.Info, http://www.tailings.info/disposal/deposition.htm

EMC (Erdenet Mining Corporation) 2015, http://www.erdenetmc.mn

MEGD (Mongolian Ministry of Environment and Green Development and Tourism) 2015, Environmental Statistical Database, http://www.eic.mn/box/search.php?action=search 